\title{
Supplementation of black soldier fly (Hermetia illucens) on productivity and blood hematology
}

\author{
Andri Cahya Irawan ${ }^{* 1)}$, Dewi Apri Astuti' ${ }^{2)}$, I Wayan Teguh Wibawan ${ }^{3)}$, Widya Hermana ${ }^{2)}$ \\ 1) Program Studi Teknologi Nutrisi dan Pakan, Fakultas Peternakan, Institut Pertanian Bogor \\ 2 )Departemen Teknologi Nutrisi dan Makanan, Fakultas Peternakan, Institut Pertanian Bogor \\ 3) Departemen Parasitologi dan Patologi, Fakultas Kedokteran Hewan, Institut Pertanian \\ Bogor \\ Jl. Agatis, Kampus IPB Dramaga Bogor 16680, Indonesia
}

Submitted: 22 July 2019, Accepted: 24 February 2020

\begin{abstract}
Black Soldier Fly larvae are natural antibiotics. The use of methanol extract in BSF larvae has a dual function, namely high protein content and high antibiotic content to kill Gram-negative bacteria. The biological structure of BSF larvae with antimicrobial peptide (AMP) acts as an inhibitor of pathogenic microorganisms, has a high lauric acid function as a natural antimicrobial and chitin, the polysaccharide plays a role in enhancing the immune response of the animal. This study aims to gain the best type of BSF protein from feed treatments containing live BSF, dry BSF, and BSF extract to increase blood productivity and hematology. The results of this study show that the best P3 treatment for the productivity of laying hens at the age of 18 to 26 weeks with the use of BSF extract since it contains the highest protein compared to other treatments. Productivity variables show the best P3 treatment, each egg weight $57.17 \mathrm{~g} \mathrm{bird}^{-1}$, daily egg production $90.88 \%$, egg mass $2408.16 \mathrm{~g}$ bird $^{-1}$ and ration conversion 2.0. The mean hematology of the blood showed the highest P3 treatment, each erythrocyte $2.91 \pm 0.13 \times 10^{6} \mathrm{~mm}^{-3}$, leucocytes $17.69 \pm 3.68 \times 10^{3} \mathrm{~mm}^{-3}$, hematocrit 27.8 $\pm 1.14 \%$, hemoglobin 9.96 $\pm 1.12 \%$, MCV 95.77 $\pm 4.41 \mathrm{fl}$, MCHC $35.99 \pm 5.21 \%$, MCH $34.38 \pm 4.53 \mathrm{pg}$, lymphocytes $61.2 \pm 4.86 \%$, heterophile $31.2 \pm 2 \%$, monocytes $5 \pm 0.62 \%$ and ratio $\mathrm{H} / \mathrm{L} 0.51 \pm 0.04$.
\end{abstract}

Keywords: black Soldier Fly (BSF); antimicrobial peptide (AMP); productivity; hematology.

*Corresponding Author: andricahyairawan91@gmail.com 


\section{INTRODUCTIONS}

AGP (antibiotic growth promoter) improves chicken performance. It is estimated that the use of AGP increases chicken growth by $4-8 \%$ and feed conversion by $2-5 \%$. The role of AGP can kill pathogenic bacteria in the digestion of chickens, such as. Salmonella sp., Campylobacter sp., Enterococci sp., and Escherichia coli. Uncontrolled and inappropriate use of antibiotics leads to microbial resistance to these antibiotics. This problem requires a solution in the form of a product that can boost livestock growth without causing resistance. AGP problems are also associated with local Indonesian fishmeal whose quality does not meet the standards of quality fish meal requirements for animal feed ingredients and whose price is high. Alternative solutions for animal protein are needed at affordable prices and as a replacement for AGP, namely Black Soldier Fly (BSF).

BSF larvae (Black Soldier Fly) have a relatively high protein content of $40-50 \%$ and a fat content of 29-32\% ( Bosch et al., 2014 ). According to Rambet et al. (2016), BSF flour has the potential role in replacing fishmeal up to $100 \%$ for broiler feeds, without affecting the digestibility of the dry matter (57.96 - 60.42\%), energy (62.03 $64.77 \%)$ and protein $(64.59-75.32 \%)$. BSF larvae also have the enzymes protease, amylase and lipase; proteases convert proteins into amino acids, amylases convert starch into maltose and lipases convert fats into fatty acids and glycerol (Kim et al., 2011). BSF larvae are natural antibiotics. BSF larvae extracted with methanol solvent have been reported to exhibit antibiotic properties in Gram-negative bacteria such as Klebsiella pneumonia, Neisseria gonorrhoeae and Shigella sonnei.

Conversely, the results of the analysis also showed that larval extracts were not effective for Gram-positive bacteria such as Bacillus subtilis, Streptococcus mutans and Sarcina lutea (Choi et al., 2012). Methanol extract from BSF larvae can inhibit the proliferation of Gram-negative bacteria and thus double their use as animal feed sources, namely high protein content and high antibiotic content, to kill harmful Gram-negative bacteria. According to Choi et al. (2012), there is an antimicrobial activity of hemophilia and BSF larval extract. The innate immune system of all insect classes has adapted well in extreme environments such as excrement, excrement, compost and organic waste containing bacteria, viruses and fungi. The biological structure of BSF larvae has antimicrobial peptides (AMPs) that act as inhibitors of pathogenic microorganisms (Park et al., 2014). This view is supported by Kim and Rhee (2016) that high lauric acid BSF larvae are a type of fatty acid that acts as a natural antimicrobial agent and chitin. Polysaccharides play a role in enhancing the immune response of the animal (Bovera et al., 2015).

Maggot is the larvae of black soldiers or flower insects. They have a strict consistency. In the digestive tract are digestive enzymes (amylase, lipase and protease), which convert organic waste into protein and body fat. Hermetia illucens larvae also have the enzymes protease, amylase and lipase. Proteases convert proteins into amino acids; amylases convert starch into maltose and lipases convert fats into fatty acids and glycerol. (Kim et al., 2011). Enzymes are a group of proteins that regulate and conduct chemical changes in biological systems. Enzymes are produced by organs in animals and plants that catalytically carry out various reactions such as hydrolysis, oxidation, reduction, isomerization, addition, radical transfer, and carbon chain breakage (Sumardjo, 2009). The nutrient content of maggots (Hermetia illucens) was among others: energy $5282 \mathrm{Kcal}$ GE / kg, crude protein $42.1 \%$, fat $26 \%$, calcium $7.56 \%$ and phosphorus $0.9 \%$ (Newton et al., 1977; Arango Gutierrez et al., 2004, St-Hillaire et al., 2007, and Makkar et al., 2014). It was reported that the calcium mineral contained 
in the BSF flour was $88 \%$ (Finke, 2012). Another advantage is that it has antimicrobial and antifungal properties so that it can increase the body's resistance to bacterial and fungal diseases.

\section{MATERIALS AND METHODS Materials}

The BSF larvae used were obtained from PT. Indo Bogor Biocycle. The larvae used received rations in the form of crude palm oil wastes and were harvested at the age of 15 days. After harvest, the larvae were treated with three forms, namely was fresh BSF, dried BSF and BSF extract.

\section{Making Feed from BSF}

Fresh BSF. In this method, a selfmixing system (basal) is used, i.e. all feed components are divided into rations according to the nutrient requirements of the laying hens, as shown in table 1. Fresh BSF is given after the basal ration has spread in the ration (topping) (Barros et al., 2014).

Dried BSF. The first stage of dried BSF production was to separate pupa from the cocoon layer by washing and steaming at $95-100^{\circ} \mathrm{C}$ for 10 minutes. The larvae were then heated to $55^{\circ} \mathrm{C}$ for 24 hours to remove the water. Then the larva was ground to the flour with a blender and put in airtight plastic. The percentage of fishmeal used in the basic ration was reduced to $5 \%$ and $8 \%$ BSF (dry). The processing of BSF by a drying process may increase the possibility of transmitting pathogenic bacteria to livestock such as Salmonella sp. (Lalander et al., 2013).

Extract BSF. The steps for producing the BSF extract were carried out according to the modified method of Choi et al. (2012). BSF larvae were washed and steamed for 10 minutes at $95-100^{\circ} \mathrm{C}$ (steam), then the larvae were heated at $55^{\circ} \mathrm{C}$ for 24 hours to remove water, then the larvae were ground to flour with a blender and then with a denanol ratio of $1: 10 \quad(\mathrm{~b} / \mathrm{v})$ for 24 hours at room temperature, then the solution was filtered out twice with Whatman paper. The extract was then evaporated using an evaporator rotary vacuum at $40^{\circ} \mathrm{C}$.

\section{Chemical Properties of BSF}

Analysis of nutrient content and amino acid composition in fresh BSF, dry BSF, and BSF extract. Nutrient content analysis methods using proximity tests with fresh BSF, dried BSF and BSF extracts, including analysis of dry matter $(\%)$, crude protein $(\%)$, crude fiber $(\%)$, crude fat $(\%)$, Ash (\%), gross energy, metabolic energy, calcium, phosphorus and $\mathrm{NaCl}$.

The analysis of protein quality in fresh BSF, dry BSF, and BSF extract consisted of chemical amino acid evaluations, amino acid content and essential amino acid index (IAAE). The first step is the analysis of the amino acid content by high-performance liquid chromatography (HPLC) according to the IK.LP-04.7-LT-1.0 method, then the calculation of the chemical scores of the amino acids and the IAAE is performed. According to McDonald et al. (2010), the formula for calculating the chemical amino acid values for fresh BSF, dried BSF and $\mathrm{BSF}$ extracts is chemical evaluation $=($ the most deficient content of essential amino acids in the sample / amino acids similar to eggs) x 100. According to McDonald et al. (2010) IAAE calculation formula for fresh BSF, dry BSF and BSF extract are:

$$
\mathrm{IAAE}=(\mathrm{A} / \mathrm{Ae} \times \mathrm{B} / \mathrm{Be} \times \mathrm{C} / \mathrm{Ce} \times \ldots \ldots \ldots \ldots \times \mathrm{J} / \mathrm{Je})^{1 / \mathrm{n}}
$$

information :
$\mathrm{A}, \mathrm{B}, \mathrm{C}, \ldots \ldots . \mathrm{J} \quad$ : concentration $(\mathrm{g} \mathrm{kg}-1)$ of fresh essential BSF amino acids
$\mathrm{Ae}, \mathrm{Be}, \mathrm{Ce}, \ldots . . \mathrm{Je} \quad$ : concentration $(\mathrm{g} \mathrm{kg}-1)$ of the same essential amino acids found in eggs
$\mathrm{n}$ : the amount of essential amino acids that are counted 
The explanation of the above formula is that the total essential amino acids contained in the tested ration material and compared with the total essential amino acids contained in foods, namely protein, are compared. The higher the IAAE value, the higher the quality of the protein. The provisions of this formula also apply to dry BSF and BSF extracts.

\section{Maintenance of Laying Hens}

Laying hens were placed in group battery cages ( 4 treatments $\mathrm{x} 5$ replications $\mathrm{x} 10$ heads). Maintenance was carried out for eight weeks, starting with the age of chicken 18 weeks to 26 weeks. Provision of $120 \mathrm{~g} / \mathrm{head} /$ day ration and drinking water was given in ad libitum. The provision of treatment rations was given twice a day at $08.00 \mathrm{am}$ and at $03.00 \mathrm{pm}$. Every day a record of the cage's temperature and humidity was carried out, feed consumption, egg production, HDP and mortality. Egg collection was carried out every day at $09.00 \mathrm{am}$, then weighing and counting the number of eggs obtained.

\section{Calculation of Production Performance of Laying Hens}

Feed consumption (g bird ${ }^{-1}$ day $^{-1}$ ). The difference in ration administration with the rest of the ration for a week. Consumption of cumulative ration and consumption of daily ration per bird. According to Scott et al. (1992), the formula for calculating ration consumption is:

Cumulative feed consumption
$\left(\mathrm{g} \mathrm{bird}^{-1}\right)$
Daily feed consumption
$\left(\mathrm{g} \mathrm{bird}^{-1}\right.$ day $\left.^{-1}\right)$

Egg weight (g bird ${ }^{-1}$ ). Egg weight was measured by daily weighing during the study and then averaged according to treatment and replication.

Hen day production (\%). The percentage comparison between the number of eggs produced by laying hens in a group for one day and the number of chickens in this group. According to Djulardi (2006), the formula for calculating Hen Day Production is:

$$
\operatorname{HDP}(\%)=\frac{\text { total eggs }}{\text { total of laying hens (bird) }} \times 100 \%
$$

Egg mass production (g bird $^{-1}$ ). Calculation of egg mass production is obtained by multiplying hen day production by egg weight.

Feed conversion. The ratio between ration consumption and body weight gain or egg mass production. According to Yuwanta (2010), the formula for calculating feed conversion is:

Feed $\quad=$ feed intake $\left(\mathrm{g}\right.$ week $\left.^{-1}\right)$ conversion egg mass production (g week ${ }^{1)}$

$$
\begin{aligned}
& =\frac{\text { feed intake }(\mathrm{g})-\text { feed leftovers }(\mathrm{g})}{\text { total of laying hens (bird) }} \\
& =\frac{\text { feed intake }(\mathrm{g})-\text { feed leftovers }(\mathrm{g})}{\text { total of laying hens (bird) } \times 7 \text { (day) }}
\end{aligned}
$$

\section{Blood drawing}

Blood sampling was carried out in the last week of the study, which is the twentysixth week; this blood sample was used for hematological analysis. When blood is drawn in the morning. Blood collection from the jugular vein is $3 \mathrm{ml}$ and put in a tube containing an anticoagulant (EDTA / Ethylenediaminetetraacetic Acid).

In vitro antibacterial activity test on fresh BSF, dry BSF and BSF extract

The preparation of the ingredients starts with the production of fresh BSF, dried BSF, and BSF extract. The next process is the sterilization of tools and media from MHA (Muller Hilton Agar). Tools and media used for antibacterial tests were sterilized using an autoclave at $121^{\circ} \mathrm{C}$ in 30 minutes. This study uses the agar diffusion method (inhibition of zone growth) against Salmonella enteritidis strains.

These bacteria were subcultured in Tryptic soy agar (TSA) medium and incubated at $350{ }^{\circ} \mathrm{C}$ for 24 hours. Bacteria derived from subcultures grown in TSA medium are suspended until a population of 
$10^{7} \mathrm{CFU} / \mathrm{ml}$ is obtained. Volumetric pipettes take up to $0.1 \mathrm{ml}$ of suspension and are then added to the MHA medium by leveling the surface of the MHA medium with a spatula. The MHA medium was allowed to stand at room temperature for 15 minutes. Fresh BSF, dried BSF, and BSF extract was mixed with a solution of dimethyl sulfoxide (DMSO) at varying concentrations, dissolved ie $10 \mathrm{mg} \mathrm{ml}^{-1} ; 20$ $\mathrm{mg} \mathrm{ml}^{-1} ; 40 \mathrm{mg} \mathrm{ml}^{-1} ; 160 \mathrm{mg} \mathrm{ml}^{-1}$ and 320 $\mathrm{mg} \mathrm{ml}^{-1}$. Medium MHA holes depressions. A solution of $20 \mu \mathrm{l}$ of fresh BSF, dry BSF and $\mathrm{BSF}$ extract from each concentration was added to a well in MHA medium and then incubated at $350^{\circ} \mathrm{C}$ for 24 to 48 hours (McBeath, 1992). Each treatment was tested for antibacterial activity as indicated by the diameter of the clear zone that forms around the hole. Evaluation of inhibition of bacteria, namely: strong with clear zones> $6 \mathrm{~mm}$, moderate with clear zones $<3-6 \mathrm{~mm}$ and weak with clear zones $<3 \mathrm{~mm}$ (Pan $e t$ al., 2009).

\section{Statistical Analysis}

Physical quality, chemical quality testing of egg-laying eggs, IOFC, blood lipid metabolism test for laying hens were analyzed using randomized design followed with an advanced test using Duncan (Mattjik dan Sumertajaya, 2002). Data processing was done by using the computer software program of Microsoft Excel 2010 and SPSS for Windows version 21.

Table 1. The composition of the isoprotein formulation and the nutrient content of the treatment ration

\begin{tabular}{lrrrr}
\hline \multirow{2}{*}{ Material } & \multicolumn{4}{c}{ Treatment (\%) } \\
\cline { 2 - 5 } Maize & 56,12 & 54,67 & 54,50 & 54,01 \\
Bran & 6,92 & 3,60 & 5,63 & 6,74 \\
Coconut oil & 1,98 & 1,95 & 1,70 & 1,96 \\
Fish meal & 8,00 & 5,00 & 5,00 & 5,00 \\
Soybean meal & 22,65 & 22,45 & 20,84 & 19,96 \\
Fresh BSF & - & 8,00 & - & - \\
Dried BSF & - & - & 8,00 & - \\
extract BSF & - & - & 8,00 \\
CaCO3 & 3,49 & 3,49 & 3,49 & 3,49 \\
Salt & 0,24 & 0,24 & 0,24 & 0,24 \\
Premix & 0,20 & 0,20 & 0,20 & 0,20 \\
Methionine & 0,20 & 0,20 & 0,20 & 0,20 \\
Lysin & 0,20 & 0,20 & 0,20 & 0,20 \\
\hline Total & 100 & 100 & 100 & 100 \\
\hline Proximate composition ${ }^{1)}$ & \multicolumn{4}{c}{} \\
\hline Crude Protein $(\%)$ & 20,16 & 20,01 & 20,00 & 20,00 \\
Crude Fat (\%) & 5,31 & 6,70 & 6,96 & 6,63 \\
Crude Fiber (\%) & 2,78 & 2,92 & 3,20 & 3,34 \\
Metabolis Energy (kkal kg $\left.{ }^{-1}\right)$ & 2900,55 & 2908,10 & 2901,43 & 2903,88 \\
Calsium (\%) & 4,00 & 4,01 & 4,00 & 4,10 \\
Phosphor (\%) & 0,36 & 0,27 & 0,27 & 0,27 \\
Lysin (\%) & 0,86 & 0,87 & 0,85 & 0,88 \\
Methionine (\%) & 0,44 & 0,44 & 0,49 & 0,45 \\
\hline Calculation rsuts bas
\end{tabular}

1) Calculation results based on Leeson and Summers (2005), P0: ration contains $8 \%$ fish meal; P1: ration with 5\% fish meal $+8 \%$ fresh BSF; P2: ration with $5 \%$ fish meal $+8 \%$ dried BSF; P3: ration with $5 \%$ fish meal $+8 \%$ extract BSF. 
RESULTS AND DISCUSSION

The quality of essential amino acids of Black Soldier Fly larvae

The results of the analysis of amino acid compositions in Black Soldier Fly larvae as compared to fish meal and eggs are shown in Table 2. Amino acids play an essential role in controlling egg size (Leeson and Summers 2005). Insects have a high crude protein content, which is composed of different types of amino acids. Three types of amino acids play an essential role in the immune system, including arginine, histidine and glutamine. According to Taruan (2012), this glutamine derives from the synthesis of the amino acid glutamic, which plays a role in immune cells.

The IAAE values in the BSF type were lower compared to the fish meal (34.08). 53.18 and 56.65. The IAAE value is determined by calculating the content of all essential amino acids in feed components compared to eggs, as the content of essential amino acids is complete/standard.

Table 2. Comparison of BSF larvae amino acid content compared with fish meal and eggs

\begin{tabular}{|c|c|c|c|c|c|}
\hline \multirow[b]{2}{*}{ Type of Amino Acid } & \multicolumn{5}{|c|}{ Contents $(\% \mathrm{~b} / \mathrm{b})^{*}$} \\
\hline & $\begin{array}{l}\text { Fresh } \\
\text { BSF }^{1)}\end{array}$ & $\begin{array}{l}\text { Dried } \\
\text { BSF }^{1)}\end{array}$ & $\begin{array}{l}\text { Extract } \\
\mathrm{BSF}^{1)}\end{array}$ & $\begin{array}{l}\text { Fish } \\
\text { meal }^{2)}\end{array}$ & $\operatorname{egg}^{3)}$ \\
\hline Histidine & 1.58 & 1.99 & 2.37 & 1.16 & 2.1 \\
\hline Threonine & 1.78 & 2.55 & 2.53 & 1.95 & 4.9 \\
\hline Tyrosine & 2.03 & 4.34 & 3.88 & 1.56 & 4.5 \\
\hline Methionine & 1.41 & 1.60 & 1.75 & 1.26 & 4.1 \\
\hline Valin & 1.92 & 2.99 & 3.74 & 2.52 & 7.3 \\
\hline Phenylalanine & 1.85 & 2.85 & 3.01 & 1.95 & 6.3 \\
\hline Isoleucine & 1.71 & 2.23 & 4.42 & 1.99 & 8 \\
\hline Leucine & 1.99 & 3.64 & 2.98 & 3.65 & 9.2 \\
\hline Lysine & 1.70 & 2.44 & 2.47 & 3.41 & 7.2 \\
\hline Arginine & 1.93 & 3.02 & 4.26 & 2.52 & 6.4 \\
\hline Serin & 1.81 & 2.49 & 4.33 & 1.69 & 8.5 \\
\hline Glutamic acid & 2.27 & 4.68 & 5.36 & 6.13 & 14.3 \\
\hline Alanine & 2.06 & 2.92 & 3.67 & 3.02 & 6.2 \\
\hline Glycine & 1.97 & 3.40 & 3.74 & 3.41 & 3.6 \\
\hline Aspartic acid & 1.97 & 3.64 & 4.32 & 4.67 & 9.4 \\
\hline Proline & 1.91 & 2.81 & 3.64 & 2.34 & 4.4 \\
\hline \multirow{2}{*}{$\begin{array}{l}\text { Chemical score }^{4)} \\
\text { essential amino acid } \\
\text { index }^{5)}\end{array}$} & 29.51 & 39.02 & 42.68 & 55.24 & 100 \\
\hline & 34.08 & 53.18 & 56.65 & 56.79 & - \\
\hline
\end{tabular}

*The content is based on total amino acids; ${ }^{1)}$ analysis results from PT. Saraswanti Indo Genetech (2019); ${ }^{2}$ Heuźe et al. $(2015) ;{ }^{3)}$ Leeson and Summers $(2005) ;{ }^{4,5}$ Calculation results are based on amino acid content (McDonald et al. 2010).

Based on Table 2, the chemical and IAAE values are directly proportional to the value of protein quality in the feed ingredients. The quality of the feed is determined by the amount of amino acid composition in the nutrients of the feed. Amino acids are divided into two groups, essential amino acids, and nonessential amino acids. Essential amino acids are easily absorbed by the body so that they support the metabolism but can not be produced in the body. Therefore, it must be added in the form of a feed to meet the nutrient needs. The amount of amino acid composition in the feed can directly affect the protein content needed to produce the 
ration (McDonald et al., 2010). The data in Table 2 show that BSF larvae have different amino acid compositions. Due to the high protein content, BSF larvae also contain all essential amino acids, in particular, methionine as a limiting factor for plant protein.

There is an equation for the highest amino acid content in live BSF. Dried BSF and BSF extract are glutamic acid, including nonessential amino acids, which equals $2.27 \%$. $4.68 \%$ and $5.36 \%$. The equation is also seen in the lowest essential amino acid content (deficiency) for live $\mathrm{BSF}$, dried BSF and BSF extract is methionine, which is $1.41 \% ; 1.60 \%$ and $1.75 \%$. Proteins and amino acids (especially methionine) play an important role in controlling egg size, poultry size, and genetic makeup (Leeson and Summers 2005).

In general, the ratio of BSF amino acid extract content is higher compared to fish meal, except for leucine, lysine, glutamic acid and aspartic acid. The method of reducing protein quality in feed ingredients can be performed by calculating the chemical and IAAE scores. The chemical evaluation of the BSF type is lower than the chemical evaluation of fish meal of $55.24 \%$. The chemical score is determined by the results of amino acid calculations, which are compared between the amino acid content of the poorest dietary constituents (lowest score) of similar amino acids to eggs, as these have a complete/standard protein. The essential amino acids contained in the egg protein have a chemical value of 100 and are therefore used as a standard/comparison of a feed component of Leeson and Summers (2005).

\section{Effect of treatment on production performance of laying hens aged 18-26 weeks}

The average performance data of laying hens aged 18 to 26 weeks during the study are shown in Table 3 . Based on the analysis results, it was found that the use of BSF larvae as a feed supplement in the diet had no significant effect on feed consumption and feed conversion, but had a significant impact on egg production and egg mass $(\mathrm{p}<0.05)$.

Tabel 3. The average performance of laying hens is $18-26$ weeks

\begin{tabular}{|c|c|c|c|c|}
\hline \multirow{2}{*}{ Variable } & \multicolumn{4}{|c|}{ Treatment } \\
\hline & $\mathrm{P} 0$ & $\mathrm{P} 1$ & $\mathrm{P} 2$ & P3 \\
\hline Feed consumption $\left(\mathrm{g} \mathrm{bird}^{-1}\right.$ day $\left.^{-1}\right)$ & 112.15 & 112.10 & 112.16 & 112.12 \\
\hline Egg weight $\left(\mathrm{g} \mathrm{bird}^{-1}\right)$ & 54.82 & 53.56 & 54.76 & 57.17 \\
\hline Hen day production $(\%)$ & 81.71 & 86.93 & 81.95 & 90.88 \\
\hline Egg mass production $\left(\mathrm{g} \mathrm{bird}^{-1}\right)$ & 1845.37 & 2064.66 & 1851.46 & 2408.16 \\
\hline Feed conversion & 2.29 & 2.17 & 2.20 & 2.00 \\
\hline
\end{tabular}

Note : Different superscripts on the same line show significant differences $(\mathrm{P}<0.05)$. P0: Ration contains $8 \%$ fish meal. P1: Ration contains $5 \%$ fish meal $+8 \%$ fresh BSF. P2: Rations containing 5\% fish meal $+8 \%$ dried BSF. P3: Ration containing 5\% fish meal $+8 \%$ BSF extract.

Several factors affect the performance of chickens in rations containing BSF larvae. First, BSF contains a lot of protein and fat, which can affect the digestibility and palatability of larvae flour. BSF Kroeckel et al. (2012). Second, the main causes of reduced feed consumption in chickens are the high ash content in BSF larvae and the higher inclusion rates in feed components (Makkar et al., 2014). Third, different or unprocessed on fresh BSF processing methods may affect the digestibility of chickens so that the whole body parts of the BSF larvae are not optimally exposed in the chicken body (Dierenfeld and King, 2009). Fourth, many studies indicate that BSF larvae flour is high in protein, but it is important to 
conduct a thorough assessment of the limiting amino acids in diets containing BSF larvae (Barragan et al., 2017). Fifth, bacteria isolated from BSF larvae can be used as probiotics to improve animal performance, such as those found in fish (Ushakova et al., 2016). Sixth, the high lipid content in BSF larvae is related to the oxidation process at high temperatures, or in the body. The BSF larvae are contained against diet, flavonoids, and terpenoids (Belluco et al. 2013, Shantibala et al., 2014). Laying hens in the laying period is faster in metabolic processes than in the growing season, as laying hens have an energy requirement for producing an egg of 65-110 kcal (Amrullah 2004).

\section{Feed consumption}

The feed consumption data for laying hens by adding different BSF treatments in the diet (P1, P2, and P3) did not differ significantly from the consumption of the control ration (P0). These data show that the addition of various mixed BSF larvae did not affect the palatability of laying hens. However, it was found that the highest consumption of $\mathrm{P} 2$ treatment ration was $112.16 \mathrm{~g}$ compared to other treatments (Table 3). According to Damayanti et al. (2017), the particle size of the feed affects the homogeneity of the distribution of feed ingredients, which correlates with the liability when mixed and processed into rations. The $\mathrm{P} 1$ treatment in this study used live BSF larvae that were carried out after the preparation of the ration by spreading (topping). However, based on the data in Table 3, the P1 treatment did not affect the ration consumption compared to the $\mathrm{P} 0, \mathrm{P} 2$, and P3 treatments. The value for laying hens in this study is lower than the standard use level for ISA BROWN laying hens 1826 weeks of age, which is $115 \mathrm{~g} \mathrm{bird}^{-1}$ day $^{-1}$ (Hendrix Genetic Company 2015).

\section{Egg weight}

Based on Table 3, the use of BSF larvae in the diet had a significant effect on egg weight $(\mathrm{P}<0.05)$. The results showed a weight at the lowest P1 treatment, while the highest P3 treatment was compared with P0 and P2 treatments. The mean value of all examined eggs ranged from 53.56 to 57.17 g, point 1 (Table 3 ).

The P3 treatment has a higher protein because it contains BSF extract as the availability of essential amino acids is more balanced, so it can more efficiently be converted to egg weight (Leeson and Summers 2005). The weight value of laying hens in this study is lower than the standard weight of ISA BROWN laying hens at the age of 18 to 26 weeks, which is $60.8 \mathrm{~g}$ of item-1 (Hendrix Genetic Company 2015). The average egg weight of the P3 treatment, i.e., rationing containing the BSF extract, was the highest compared to other treatments. Several factors affecting egg weight include genetics, age, diet, poultry body size, climate, egg production, protein, and amino acids (especially methionine), which play an important role in the control of egg size. Leeson and Summers (2005).

\section{Hen day production}

Based on Table 3, the use of BSF larvae in the diet had a significant effect on egg weight $(\mathrm{P}<0.05)$. The results of the analysis of variance showed that egg production was highest in P3 treatment compared to other treatments, namely, $90.88 \%$. The production value of laying hen eggs in this study is below the standard value of ISA BROWN for laying hens production at $96 \%$ after 26 weeks (Hendrix Genetic Company 2015). According to Farooq et al. (2002) are various factors influencing egg production, chicken stocks, the age of first oviposition, ration, mortality, clubbing, health and maintenance management, maximum egg production and persistence of oviposition. The research results of Kirunda et al. (2001) have the result that at high temperatures, the egg production of white Leghorns decreases. High ambient temperatures lead to a decrease in egg production, so more energy is needed to help the laying hens to regulate their body temperature, while a reduction in feed consumption results in a reduced diet of the body, resulting in reduced egg 
production (Bird et al. 2003) and Mashaly et al. (2004). Low feed consumption and energy consumption during the production phase can lead to a reduction in egg production and mass (Widjastuti et al., 2014).

\section{Egg mass production}

Based on Table 3, the use of BSF larvae in the diet significantly affected the egg period $(\mathrm{P}<0.05)$. The average egg mass production during this study ranged from 1845.37 to $2408.16 \mathrm{~g} \mathrm{bird}^{-1}$ (Table 3). The P3 treatment had a higher egg mash value than the normal ISA BROWN lay 26 weeks at $2300 \mathrm{~g} \mathrm{bird}^{-1}$ (Hendrix Genetic Company 2015), whereas the P0, P1, and P2 treatments had a lower than egg standard P0 was $1845.37 \mathrm{~g} \mathrm{bird}^{-1}$, P1 was $2064.66 \mathrm{~g}$ bird $^{-1}$ and P2 was $1851.46 \mathrm{~g} \mathrm{bird}^{-1}$. The quality of the protein in the ration plays an important role in the production of egg mass, which correlates closely with egg weight and egg production. According to Mousavi et al. (2013) that the balance of protein and amino acid content in the diet can increase optimal productivity. Egg mass values are influenced by heat stress, egg production and egg weight (Vercese $e t$ al., 2012). Sh et al. (2013) found that the value of low egg mass production correlated positively with the value of low egg mass production, while egg mass production was the result of egg daily egg production.

\section{Feed conversion}

Based on Table 3, the use of BSF larvae in the diet had no significant effect on feed conversion $(\mathrm{P}<0.05)$. The average ration conversion in this study ranged from 2.29 to 2.00 (Table 3). The P3 treatment had the lowest conversion value of 2.00, the provision of $\mathrm{BSF}$ extract-containing rations had no significant effect on feed conversion to laying hens. The ratio of ration consumption between treatments was not very different, but the P3 treatment had the highest egg weight, the highest daily egg production and the highest egg mass compared to other treatments. The P3 treatment has a lower ration conversion value compared to the standard conversion of ISA BROWN laying hens at 26 weeks from 1.95 (Hendrix Genetic Company 2015).

The P1 treatment has a feed conversion value of 2.17 , the provision of BSF containing rations also has no significant effect on feed conversion in laying hens, indicating that the BSF seeding method of life after ration preparation (topping) has no significant effect the feed conversion has $(\mathrm{P}<0.05)$. One of the parameters for the efficiency of livestock in the conversion of spent rations is that the conversion value of the rations is lower than between treatments, as the conversion value of the rations increases, the higher the cost of production (expensive). Some factors influencing ration transformation are egg production, nutrient nutrition and egg weight. Research by Cayan and Erener (2015) has shown that the conversion of 22 weeks of old Lohmann brown chicken rations fed with olive leaf meal is 2.05-2.07.

\section{Effect of treatment on blood hematology of 26-week-old laying hens}

Mean hematological data from 26week old laying hens are shown in Table 4. Based on the analysis results, it was found that the use of BSF larvae as fish meal supplement feed had no significant effect on the erythrocytes, the mean corpuscular hemoglobin concentration (MCHC) and the mean corpuscular concentration volume (MCV), mean corpuscular hemoglobin $(\mathrm{MCH})$, heterophile / Lymphocyte (H/L) ratio, however, has a significant effect on hematocrit, leukocytes, hemoglobin, lymphocytes, heterophile and monocytes $(\mathrm{P}<0.05)$. According to Guyton and Hall (2010), cattle have normal hematology in healthy conditions.

Each component of the blood cells circulates in blood vessels. Hematologic features of the blood aim to determine the onset of the disease and to provide information on physiological changes and pathological conditions. External causes of physiological changes are microorganism 
diseases and changes in ambient temperature, while changes are caused internally by age, nutritional status, health, body heat and stress (Guyton and Hall 2010). The hematological profile of the blood is influenced by the provision of rations containing different $\mathrm{BSF}$ types for each treatment. Based on Table 2, the amount of amino acid composition in feeds can improve the ration quality so that the protein performance in the ration can be met (McDonald et al., 2010). Rations containing live BSF have advantages, namely a high lauric acid content, which acts as a natural antimicrobial agent (Bovera et al., 2015). Living BSF has a high chitin content so it can enhance the body's immune response (Schiavone et al., 2017). The antimicrobial content of peptides derived from amino acids can inhibit the growth of pathogenic bacteria in the digestive tract (Park et al. 2014), whereas dried BSF and BSF extracts have no chitin during processing due to the steam process.

Chitin is a fibrous protein that is not water-soluble but is damaged by denaturation (Klunder et al., 2012). The benefit of dry BSF is a longer storage life of the feed as it eliminates water content and reduces fat (Klunder et al., 2012). The ration containing additional BSF has advantages, namely, that BSF larvae extracted with methanol as a solvent have antibiotic properties in Gram-negative bacteria (Choi et al., 2012), so their use as an animal feed source has a dual function, namely high protein content and high antibiotic content to kill harmful Gramnegative bacteria.

Table 4. Hematological mean blood of laying hens aged 26 weeks

\begin{tabular}{|c|c|c|c|c|c|}
\hline \multirow{2}{*}{ Variable } & \multicolumn{4}{|c|}{ Treatment } & \multirow[t]{2}{*}{ Standard } \\
\hline & $\mathrm{P} 0$ & $\mathrm{P} 1$ & $\mathrm{P} 2$ & $\mathrm{P} 3$ & \\
\hline $\begin{array}{l}\text { Erythrocytes }\left(10^{6}\right. \\
\left.\mathrm{mm}^{-3}\right)\end{array}$ & $2.61 \pm 0.16$ & $2.9 \pm 0.21$ & $2.82 \pm 0.39$ & $2.91 \pm 0.13$ & $1.3-4.5^{1}$ \\
\hline $\begin{array}{l}\text { Leukocytes }\left(10^{3} \mathrm{~mm}^{-}\right. \\
\left.{ }^{3}\right)\end{array}$ & $\begin{array}{c}15.71 \pm \\
3.47\end{array}$ & $16.17 \pm 2.2$ & $15.4 \pm 2.61$ & $\begin{array}{c}17.69 \pm \\
3.68\end{array}$ & $12-30^{1}$ \\
\hline Hematocrit (\%) & $\begin{array}{l}24.80 \pm \\
1.44^{\mathrm{b}}\end{array}$ & $\begin{array}{c}27.60 \pm \\
1.33^{\mathrm{a}}\end{array}$ & $\begin{array}{l}26.60 \pm \\
1.33^{\mathrm{ab}}\end{array}$ & $\begin{array}{c}27.80 \pm \\
1.14^{\mathrm{a}}\end{array}$ & $22-55^{1}$ \\
\hline Hemoglobin $(\%)$ & $8.56 \pm 0.66$ & $9.64 \pm 0.63$ & $9.2 \pm 0.68$ & $9.96 \pm 1.12$ & $7-18^{1}$ \\
\hline $\operatorname{MCV}(\mathrm{fl})$ & $\begin{array}{l}95.17 \pm \\
3.25\end{array}$ & $\begin{array}{l}95.24 \pm \\
3.43\end{array}$ & $\begin{array}{c}95.63 \pm \\
9.53\end{array}$ & $\begin{array}{c}95.77 \pm \\
4.41\end{array}$ & $90-140^{2}$ \\
\hline $\mathrm{MCHC}(\%)$ & $\begin{array}{c}34.73 \pm \\
4.14\end{array}$ & $35 \pm 2.7$ & $\begin{array}{l}34.64 \pm \\
2.76\end{array}$ & $\begin{array}{c}35.99 \pm \\
5.21\end{array}$ & $26-36^{2}$ \\
\hline $\mathrm{MCH}(\mathrm{pg})$ & $\begin{array}{c}33.04 \pm \\
4.06\end{array}$ & $\begin{array}{l}33.35 \pm \\
3.12\end{array}$ & $\begin{array}{c}33.37 \pm \\
5.84\end{array}$ & $\begin{array}{l}34.38 \pm \\
4.53\end{array}$ & $33-47^{2}$ \\
\hline Lymphocytes (\%) & $\begin{array}{l}50.80 \pm \\
5.06^{\mathrm{b}}\end{array}$ & $\begin{array}{c}58.60 \pm \\
3.37^{\mathrm{ab}}\end{array}$ & $\begin{array}{c}52.80 \pm \\
2.8^{\mathrm{ab}}\end{array}$ & $\begin{array}{c}61.20 \pm \\
4.86^{\mathrm{a}}\end{array}$ & $29-84^{1}$ \\
\hline Heterophil (\%) & $\begin{array}{l}25.20 \pm \\
1.14^{\mathrm{b}}\end{array}$ & $\begin{array}{l}28.40 \pm \\
3.19^{\mathrm{ab}}\end{array}$ & $\begin{array}{l}25.20 \pm \\
1.69^{\mathrm{b}}\end{array}$ & $\begin{array}{l}31.20 \pm \\
2.00^{\mathrm{a}}\end{array}$ & $15-50^{1}$ \\
\hline Monocyte (\%) & $3.4 \pm 1$ & $4.8 \pm 0.73$ & $3 \pm 0.62$ & $5 \pm 0.62$ & $0-7^{1}$ \\
\hline $\operatorname{Rasio}(\mathrm{H} / \mathrm{L})$ & $0.5 \pm 0.04$ & $0.49 \pm 0.06$ & $0.48 \pm 0.03$ & $0.51 \pm 0.04$ & $\begin{array}{l}0.45- \\
0.50^{1}\end{array}$ \\
\hline
\end{tabular}

Note : Different superscripts on the same line show significant differences $(\mathrm{P}<0.05)$. P0: Ration contains $8 \%$ fish meal. P1: Ration contains $5 \%$ fish meal $+8 \%$ fresh BSF. P2: Rations containing 5\% fish meal $+8 \%$ dried BSF. P3: Ration containing 5\% fish meal $+8 \%$ BSF extract. ${ }^{1}$ Campbell et al (2012); ${ }^{2}$ Schalms et al (2010). 


\section{Erythrocytes}

Feeding fishmeal with different types of BSF larvae had no significant effect on the number of erythrocytes (Table 4). The average number of laying hens in this study ranged from 2.61 to $2.91 \times 106 \mathrm{~mm}^{-3}$. The average erythrocyte value of laying hens in the study was $1.3-4.5 \times 106 \mathrm{~mm}^{-3}$ in the normal range of erythrocytes (Campbell et $a l ., 2012)$. The quality of red blood cells is influenced by nutrients, hemoglobin levels, and hematocrit. Chicken bodies in healthy conditions take place in normal metabolic processes so that the absorption of nutrients for the formation of red blood cells can be optimal, especially protein and vitamins are sufficient for the chicken needs. The blood always maintains a stable state in order to maintain a balance of physiological changes in the interior, so that the body functions normally. Blood needs enough protein for the formation of erythrocytes to maintain the body's homeostasis (Dellmann and Brown 1992).

The red color of the blood cells is caused by the content of hemoglobin, which consists of protein and oxygen uptake by the lungs. When the blood flows through the body, hemoglobin releases oxygen and binds to carbon dioxide (Kahn 2005). According to Zhu et al. (2005), the content of polyunsaturated fatty acids with high concentrations in erythrocytes causes oxidative stress on erythrocyte cells. The cause of hemolysis is the content of radical compounds with excessive amounts in erythrocytes causing cell membrane damage and hemoglobin leaking from the cell. Various factors that affect the number of erythrocytes include physiological status, chicken age, sex, chicken activity, nutritional content in the diet, and environmental conditions (temperature and humidity) (Guyton and Hall 2010, Campbell 2015). According to Scanes (2015), poultry has a higher body temperature and metabolism rate compared to mammals due to the short lifespan and phylogically resistant poultry, so that there is a slight reduction in the number of erythrocytes compared to mammals (Campbell 2015).

\section{Leukocytes}

Based on the analysis of variance, the provision of fish meal-containing rations with various species of BSF larvae had a significant effect $(\mathrm{P}<0.05)$ on the average number of leukocytes. The average number of laying hens in this study, according to Ihwantoro (2014), was between 15.40 and $17.69 \times 103 \mathrm{~mm}^{-3}$ and was $22.24 \pm 6.11$ and $27.34 \pm 4.88$. The average value of laying hens in this study is in the normal leukocyte range of $12.0-30.0 \times 103 \mathrm{~mm}^{-3}$ (Campbell et al., 2012). This shows that not all treatments in this study were indicated to be infected by specific pathogens. According to Moyes and Schutle (2008), high leucocyte counts can not be considered a pain/stress burden for livestock, as the increased leukocyte count aims to respond quickly and humorously to pathogenic pathogens in the body. Leukocytes play an active role in responding to the body's immunity. There are two ways in which the leukocyte defense system is formed by the body's defense mechanism (antibodies) when foreign substances enter the body and directly destroy bacteria, viruses and other foreign substances. According to Frandson (1992), the nature of leukocytes in the bloodstream does not work when infected tissue is detected, and leukocytes are alert to nonspecific disorders such as viral and bacterial infections that form an active immune system. Infections and inflammation in the body can lead to leukocytosis (Weiss and Wardrop, 2010). Foreign bodies that cause infection respond quickly because leukocytes are active and robust antibody-forming entities (Guyton and Hall 2010). This is the ability of the nucleus to move independently and actively respond to pathogens that invade the body (Campbell 2015).

\section{Hematocrit}

Hematocrit is the percentage of red blood cells from whole blood (whole blood). The hematocrit values when using 
live BSF, BSF dry extract, and BSF in the ration are significantly higher $(\mathrm{P}<0.05)$, respectively, at $8 \%$ than in control. The highest hematocrit in P3 was $27.80 \%$ (Table 4).

The average number of hematocrit hens in this study ranged from 24.80 to $27.80 \%$ over the Ihwantoro study (2014) and was $23.33 \pm 0.75 \%$. The average hematocrit of laying hens in this study is within the normal range of hematocrit of 22-55\% (Campbell et al., 2012). Some factors that affect the hematocrit value are the country and type of animals, age and production phase, gender, disease, and climate. According to Guyton and Hall (2010), a low hematocrit below normal is an indicator of why chickens develop anemia when testing for an erythrocyte index because the hematocrit value correlates positively with the number of erythrocytes (Scanes 2015). The number of erythrocytes that exceeds the normal limit results in higher hematocrit (Guyton and Hall 2010) because erythrocytes have the largest cell mass in the blood (Virden et al., 2007). The hematocrit test is used to analyze the status of blood normality, anemia, and polysetamy, as well as the indicator of oxygen transport capacity, i.e., the ability of the blood to carry oxygen (O2) throughout the body. The effect of a decrease in oxygen transport capacity is caused by an increased plasma volume in the blood, although the number of erythrocytes does not decrease (Wagner et al., 2008). Laying hens are resistant to physiological changes from the inside in order to maintain the balance of the body's environment (homeostasis). Therefore, the hematocrit level tends to decrease in the laying of eggs due to the process of hemodilution, i.e., an increase in the plasma volume and an increase in the erythrocyte mass. Plasma levels normalize after ovulation of the last follicle (Challenger et al., 2001; Vézina et al., 2003).

\section{Hemoglobin}

Hemoglobin levels were significantly higher $(\mathrm{P}<0.05)$ than the control when using different BSF types in the diet, respectively, at $8 \%$. The highest hemoglobin level at P3 was $9.96 \%$ (Table 4). The average amount of hemoglobin in laying hens in this study was between $8.56 \%$ and $9.96 \%$ higher than that of Ihwantoro (2014) and was $7.26 \pm 0.25 \%$. The average hemoglobin level in laying hens in this study is within the normal hemoglobin level, which is between $7.0 \%$ and $18.0 \%$ (Campbell et al., 2012). According to Weiss and Wardrop (2010), oxygen levels and the number of erythrocytes can influence hemoglobin levels. When the number of erythrocytes is low, the hemoglobin value also decreases. Hemoglobin has a high affinity for oxygen, contains iron-rich protein, has a red pigment in erythrocytes, and an indicator of oxygen availability in the blood. The protein content in the ration is mixed with iron to form hemoglobin, a complex organic compound containing four red porphyrin pigments (heme) as part of hemoglobin, which contains iron atoms plus globin as part of Frandson's globular protein (1992), heme combines Using the protein globin forms a hemoglobin chain that acts as a distributor of oxygen $\left(\mathrm{O}_{2}\right)$ that transports carbon dioxide $(\mathrm{CO} 2)$ from the tissues to the lungs (Guyton and Hall 2010).

MCV

Based on the analysis of variance, the provision of fish meal-containing rations with various species of BSF larvae had no significant influence $(\mathrm{P}<0.05)$ on $\mathrm{MCV}$. The average MCV of laying hens in this study ranged from 92.41 to $95.77 \mathrm{fl}$ in the normal MCV range from 90.0 to 140.0 femtoliters (Schalms et al., 2010). Research data (Table 4) shows that feeding rations containing fishmeal with various BSF larvae do not affect the size of red blood cells in laying hens during treatment, which means that in laying hens, no anemia occurs. The median corpuscular volume is an erythrocyte index analysis used to determine the status of anemia in cattle based on erythrocyte size (Guyton and 
Hall, 2008). The value of MCV is used to classify the type of anemia (Schalms et al., 2010).

\section{MCHC}

Based on the analysis of variance, the provision of fish meal-containing rations with various species of BSF larvae had no significant influence $(\mathrm{P}<0.05)$ on the MCHC. The average MCHC of laying hens in this study ranged from 34.73 to $35.99 \%$ in the same range as in the Ihwantoro study (2014) and compared the maintenance of open house systems between domestic chickens and commercial laying hens after 32 weeks each $30.20 \pm 5.58 \%$ and $27.80 \pm$ $1.52 \%$.

The average MCHC of the laying hens in this study is in the MCHC standard range of $26.0-36.0 \%$ (Schalms et al., 2010). Research data (Table 4) show that feeding rations containing fishmeal with various types of BSF larvae did not affect the concentration of hemoglobin in red blood cells in laying hens during the treatment period. Mean corpuscular hemoglobin concentration is an erythrocyte index analysis used to determine the status of anemia in cattle based on hemoglobin concentration (Guyton and Hall 2008) and to determine the value of $\mathrm{MCHC}$ for calculating hemoglobin and hematocrit levels (Fischbach and Marshall 2009).

\section{MCH}

Based on the analysis of variance, the provision of fish meal-containing rations with various species of BSF larvae had no significant effect $(\mathrm{P}<0.05)$ on $\mathrm{MCH}$. The average $\mathrm{MCH}$ of laying hens in this study ranged from 32.65 to $34.38 \mathrm{pg}$ in the normal range of $\mathrm{MCH}$, between 33.0 and 47.0 pg (Schalms et al., 2010). Research data in Table 4 show that feeding rations containing fishmeal with various BSF larvae did not affect the weight of red blood cell hemoglobin in laying hens during the treatment period. Mean Corpuscular Hemoglobin is an erythrocyte index analysis used to determine the status of anemia in cattle based on the weight of hemoglobin (Guyton and Hall 2008).

\section{Lymphocytes}

Lymphocytes are differentiations of leukocytes that have no granules. Lymphocyte counts using different BSF types in the diet were significantly $(\mathrm{P}<0.05)$ significantly higher, respectively, than the control (8\%). The highest lymphocyte value at P3 was $60.40 \%$ (Table 4). The average number of laying hen lymphocytes in this study ranged from 50.80 to $60.40 \%$, more than the Ihwantoro (2014) study $(21.06 \pm 9.02 \%)$. The average value of laying hen lymphocytes in this study is in the normal range of lymphocytes, namely between 29.0 and $84.0 \%$ (Campbell et al., 2012).

Lymphocyte counts correlate positively with the ability to adapt, laying hens to ambient temperature. According to Davis et al. (2008), high levels of corticosteroid hormone production are caused by a hot environment, so that high corticosteroid hormone levels in the blood can inhibit lymphocyte formation. According to Ganong (2008), the cause of lymphocyte levels above normal is pathological factors, lymphocytes work harder to eliminate foreign bodies entering the body, while the cause of lymphocyte levels below normal is the lack of challenges (viruses or bacteria) that invade the body (Odetola et al 2012).

According to Tizard (2000), lymphocytes are divided into two, namely T-lymphocytes (T-cells) derived from the thymus and functioning as cellular immune response cells, and B-lymphocytes (Bcells) derived from the exchanges produced Form antibodies from plasma cells resulting from humoral immune responses. Lymphocytes can respond to macrophagelinked antigens by producing antibodies as special effector cells (Tizard 2000). According to Nicholas (2004), B lymphocytes (B cells) play a role in antibody production (immunoglobulin) by forming humoral mediated immunity (HMI), while T lymphocytes ( $\mathrm{T}$ cells) play a role in cytotoxic production to destroy drug-infected cells disease by cytoytoxic $\mathrm{T}$ 
cells (Tc), which form cell-mediated immunity (CMI).

\section{Heterophile}

Heterophilic values using different BSF types in the diet, each $8 \%$ significantly $(\mathrm{P}<0.05)$ significantly higher than the control. The average number of heterophile laying hens in this study ranged from 26.40 to $32.60 \%$, which was higher than that of Ihwantoro (2014), which equals $71.55 \pm$ $10.37 \%$. The average value of heterophile laying hens in this study is within the normal range of 15.0-50.0\% (Campbell et al., 2012). Heterophyll is a phagocytic cell that contributes to the phagocytosis of germs and viruses. The highest heterophile value at P3 was $32.60 \%$ (Table 4), which means that in $\mathrm{P} 3$ treatment, the use of BSF extracts in rations had great potential for controlling germ and viral infections by producing nonspecific immune responses.

According to Campbell (2015), heterophile act phagocytically and against pathogens by penetrating and destroying the endothelial wall. According to Tizard (2000), the main function of heterophiles is to destroy foreign material through the process of phagocytosis. Heterophyll is the first defense system in which infections and granulocytes occur in most birds. Some factors that affect the value of heterophiles in the blood are infections (bacteria, fungi, viruses and parasites), inflammation, stress, certain toxicities, trauma and leukemia. Regions of the body in which infection is present are controlled by heterophiles by penetrating the endothelial wall and destroying drugs and increasing their numbers when an acute infection occurs. According to Schalms et al. (2010), heterophiles act as the first defense in poultry, inhibiting bacteria by attachment, chemotaxis, phagocytosis and killing of bacteria. Heterophyll can be affected by genetic and antimicrobial properties that positively correlate with disease resistance in the body (Redmon et al., 2011).

\section{Monocytes}

Monocytes are the differentiation of leukocytes without granules and as precursors of macrophages in the bloodstream. Monocyte values using different BSF types in the diet, each $8 \%$ significantly $(\mathrm{P}<0.05)$ significantly higher than the control. The highest monocyte value at P3 was $5.00 \%$ (Table 4). The average number of laying hens monocytes in this study, according to Ihwantoro (2014), was between 3.00 and $5.00 \%$, at $6.17 \pm 2.50 \%$. The average value of laying hens monocytes in this study is in the normal range of monocytes, which is between 0 and 7.0\% (Campbell et al., 2012). The average normal monocyte value indicates that the status of laying hens is healthy, has no physiological disorders or acute infections.

According to Mitchell and Johns (2008), monocytes are the second defense system after heterophiles, and monocytes transform into macrophages when inflammation occurs in body tissue. Monocytes produce non-specific immunity through phagocytosis, forming macrophages (Hamzah et al., 2012). Monocytes and heterophiles have phagocytic abilities, i.e., they eat foreign bodies. The difference is that monocytes are not yet able to overcome acute infections and overcome heterophilic acute infections and die after their work. The function of monocytes is to respond immediately to infections caused by pathogens by migrating into inflamed tissue areas and turning into macrophage cells. Another task of monocyte/macrophage cells is to supply antigens to lymphocytes, which interact in the immune system as the first defense against diseases and heat stress. Subowo (2009).

\section{Ratio Heterophile / Lymphocyte (H/L)}

The value of the $\mathrm{H} / \mathrm{L}$ ratio using different BSF types in the diet is significantly $8 \% \quad(\mathrm{P}<0.05) \quad$ significantly higher than the control. The highest value of the $\mathrm{H} / \mathrm{L}$ ratio at $\mathrm{P} 3$ was 0.51 (Table 4 ). According to Ihwantoro (2014), the average $\mathrm{H} / \mathrm{L}$ ratio of laying hens in this study ranged from 0.48 to 0.51 and was $3.47 \pm$ 0.57 . The average $\mathrm{H} / \mathrm{L}$ ratio of laying hens 
in this study is in the normal range of $\mathrm{H} / \mathrm{L}$ ratios of $0.45-0.50$ (Campbell et al., 2012).

The measurement of the $\mathrm{H} / \mathrm{L}$ ratio aims to capture the challenge levels of poultry as the main indicator. Ambient temperature is a major factor in poultry stress, especially during the day, as there is a risk of heat stress being negative. The mechanism of endoctrine is used in poultry to maintain the balance of normal body state under stress (Mostl and Palme 2002). For example, glucocorticoid secretion in the blood increases when the laying hens are under heat stress. The value of the H/L ratio may increase as the heat stress condition causes a decrease in lymphocyte counts (Zulkifli et al., 2000, Altan et al., 2000). Increased secretion of glucocorticoid hormones may affect the immune system as it interferes with interleukin (IL) performance. This type of cytokine plays an important role as a cell messenger in the antibody system (Blecha 2000).

\section{CONCLUSION}

The results of this study showed that the best P3 treatment for laying hens productivity was $18-26$ weeks old with the use of BSF extract because it contained the highest protein compared to other treatments. The mean hematological blood values indicate the highest $\mathrm{P} 3$ treatment.

\section{ACKNOWLEDGEMENT}

The authors gratefully acknowledge Prof. Dewi Apri Astuti, Prof. I Wayan Teguh Wibawan and Dr. Widya Hermana for technical support, and PT. Biocycle Indo Bogor for the provision of the Hermetia illucens.

\section{REFERENCES}

Altan, O., Altan, A., Cabuk, M., \& Bayraktar, H. (2000). Effects of heat stress on some blood parameters in broilers. Turkish Journal of Veterinary and Animal Sciences, 24(2), 145-148.
Altan, Ö., Pabuçcuoğlu, A., Altan, A., Konyalioğlu, S., \& Bayraktar, H. (2003). Effect of heat stress on oxidative stress, lipid peroxidation and some stress parameters in broilers. British Poultry Science, 44(4), 545-550. https://doi.org/10.10 80/00071660310001618334

Amrullah, I. (2004). Nutrisi Ayam Petelur. Bogor: Lembaga Satu Gunungbudi.

Barragan-Fonseca, K., Dicke, M., \& van Loon, J. J. (2017). Nutritional value of the black soldier fly ( Hermetia illucens L.) and its suitability as animal feed - a review. Journal of Insects as Food and Feed, 3(2), 105120. https://doi.org/10.3920/JIFF2016. 0055

Barros-Cordeiro, K. B., Báo, S. N., \& Pujol-Luz, J. R. (2014). Intra-puparial development of the black soldierfly,Hermetia illucens. Journal of Insect Science, 14(1), 1-10. https:// doi.org/10.1093/jis/14.1.83

Belluco, S., Losasso, C., Maggioletti, M., Alonzi, C. C., Paoletti, M. G., \& Ricci, A. (2013). Edible insects in a food safety and nutritional perspective: a critical review. Comprehensive Reviews in Food Science and Food Safety, 12(3), 296313. https://doi.org/10.1111/1541-433 7.12014

Bird, N., Huton, P., Morrison, W., \& Weber, L. (2003). Heat Stress in Caged Layers. Ontario: Ministry of Agriculture and Food.

Blecha, F. (2000). Immune System Response to Stress. (G. Moberg \& J. Mench, Eds.). New York: Cabi Publishing.

Bosch, G., Zhang, S., Oonincx, D. G. A. B., \& Hendriks, W. H. (2014). Protein quality of insects as potential ingredients for $\mathrm{dog}$ and cat foods. Journal of Nutritional Science, 3, 14. https://doi.org/10.1017/jns.2014.23

Bovera, F., Piccolo, G., Gasco, L., Marono, S., Loponte, R., Vassalotti, G., Nizza, A. (2015). Yellow mealworm 
larvae ( Tenebrio molitor, L.) as a possible alternative to soybean meal in broiler diets. British Poultry Science, 56(5), 1-7. https://doi.org/ 10.1080/00071668.2015.1080815

Campbell, T. (2015). Exotic Animal Hematology and Cytology (4th ed.). Oxford: John Wiley \& Sons, inc.

Campbell, T., Mary, A., \& Glade, W. (2012). Veterinary Hematology and clinical chemistry (2nd ed.). Colorado: Fort Collins.

Cayan, H., \& Erener, G. (2015). Effect of olive leaf (Olea europaea) powder on laying hens performance, egg quality and egg yolk cholesterol levels. Asian-Australasian Journal of Animal Sciences, 28(4), 538-543. https://doi. org/10.5713/ajas.14.0369

Challenger, W. O., Williams, T. D., Christians, J. K., \& Vézina, F. (2001). Follicular development and plasma yolk precursor dynamics through the laying cycle in the european starling ( Sturnus vulgaris ). Physiological and Biochemical Zoology, 74(3), 356365. https://doi.org/10.1086/320427

Choi, W.-H., Yun, J.-H., Chu, J.-P., \& Chu, K.-B. (2012). Antibacterial effect of extracts of Hermetia illucens (Diptera: Stratiomyidae) larvae against Gramnegative bacteria. Entomological Research, 42(5), 219-226. https://doi. org/10.1111/j.17485967.2012.00465.x

Damayanti, R., Lusiana, N., \& Prasetyo, J. (2017). Studi pengaruh ukuran partikel dan penambahan perekat tapioka terhadap karakteristik biopelet dari kulit coklat (Theobroma Cacao L.) sebagai bahan bakar alternatif terbarukan. Jurnal Teknotan, 11(1), 51-60. https://doi. org/10.24198/jt.vol11n1.6

Davis, A. K., Maney, D. L., \& Maerz, J. C. (2008). The use of leukocyte profiles to measure stress in vertebrates: a review for ecologists. Functional Ecology, 22(5), 760-772. https://doi.or $\mathrm{g} / 10.1111 / \mathrm{j} .1365-2435.2008 .01467 . \mathrm{x}$

Dellman, H., \& Brown, E. (1992). Histologi
Veteriner. (R. Hartono, Ed.). Jakarta: Universitas Indonesia Press.

Dierenfeld, E. S., \& King, J. (2008). Digestibility and mineral availability of phoenix worms, hermetia illucens, ingested by mountain chicken frogs, leptodactylus fallax. Journal of Herpetological Medicine and Surgery, 18(3), 100-105. https://doi. org/10.5818/1529-9651.18.3-4.100

Djulardi, A., Muis, H., \& Latif, S. A. (2006). Nutrisi Aneka Ternak dan Satwa Harapan. Padang: Universitas Andalas.

Finke, M. D. (2013). Complete Nutrient content of four species of feeder insects. Zoo Biology, 32(1), 27-36. https://doi.org/10.1002/zoo.21012

Fischbach, F., \& Marshall, B. D. (2009). A Manual of Laboratory and Diagnostic (8th ed.). Philadelphia: Williams \& Wilkins.

Frandson, R. (1992). Anatomi dan Fisiolgi Ternak. (B. Srigandono \& P. Koen, Eds.) (4th ed.). Yogyakarta: Gadjah Mada University Press.

Ganong, E. (2008). Buku Ajar Fisiologi Kedokternan (Review of Medical Physiology) (2nd ed.). Jakarta: Penerbit Buku Kedokteran EGC.

Gillespie, J., \& Flanders, F. (2010). Modern Livestock and Poultry Production (8th ed.). New York: Delmar Cengage Learning.

Gutiérrez, G. P. A., Ruiz, R. A. V., \& Vélez, H. M. (2004). Compositional, microbiological and protein digestibility analysis of larval meal of Hermetia illucens (Diptera:Stratiomyiidae) at Angelópolis-Antioquia, Colombia. Revista - Facultad Nacional de Agronomía Medellín, 57(2), 2491-2499.

Guyton, A., \& Hall, J. (2010). Textbook of Medical Physiology (8th ed.). Missisipi: Elsevier Inc.

Hamzah, R., Wiryanti, I., Astuti, D., \& Satrija, F. (2014). Tanggap kebal dan tampilan produksi ayam pedaging yang diberi ekstrak buah mengkudu. Jurnal Veteriner, 13(1), 34-42. 
Harlystiarini, H., Mutia, R., Wibawan, I. W. T., \& Astuti, D. A. (2019). In vitro antibacterial activity of black soldier fly (hermetia illucens) larva extracts against gram-negative bacteria. Buletin Peternakan, 43(2), 125-129. https://doi.org/10.21059/bul etinpeternak.v43i2.42833

Hendrix Genetic Company. (2015). Isa Brown Management Guide. Peterborough: Hendrix Genetic Company.

Heuzé, V., Tran, G., \& Kaushik, S. (2015). Fish meal. Feedipedia, program dari INRA, CIRAD, AFZ and FAO.

Khan, C. (2005). The Merk Veterinary Manual (9th ed.). Philadelphia: Nutritional Publishing.

Kim, S. A., \& Rhee, M. S. (2016). Highly enhanced bactericidal effects of medium chain fatty acids (caprylic, capric, and lauric acid) combined with edible plant essential oils (carvacrol, eugenol, $\beta$-resorcylic acid, trans cinnamaldehyde, thymol, and vanillin) against Escherichia coli O1. Food Control, 60, 447-454. https://doi.org /10.1016/j.foodcont.2015.08.022

Lesson, S., \& Summer, J. D. (2005). Comercial Poultry Nutrition (3rd ed.). Canada: University Guelph.

Mashaly, M. M., Hendricks, G. L., Kalama, M. A., Gehad, A. E., Abbas, A. O., \& Patterson, P. H. (2004). Effect of heat stress on production parameters and immune responses of commercial laying hens. Poultry Science, 83(6), 889-894. https://doi.org/10.1093/ps/8 3.6 .889

Mattjik, A., \& Sumertajaya, M. (2002). Perancangan Percobaan dengan Aplikasi SAS dan Minitab (2nd ed.). Bogor: IPB Press.

McBeath, W. (1992). Compendium for the Microbiological Examinations of Foods (3rd ed.). USA: American Public Health Association.

McDonald, P., Edwards, R., Greenhalgh, J. F., Morgan, C., Sinclair, L., \& Wilkinson, R. (2010). Animal
Nutrition (7th ed.). Pearson Education Limited.

Mitchell, E. B., \& Johns, J. (2008). Avian hematology and related disorders. Veterinary Clinics of North America: Exotic Animal Practice, 11(3), 501522. https://doi.org/10.1016/j.cvex.20 08.03.004

Möstl, E., \& Palme, R. (2002). Hormones as indicators of stress. Domestic Animal Endocrinology, 23(1-2), 6774. https://doi.org/10.1016/S0739-72 40(02)00146-7

Mousavi, S. N., Khalaji, S., GhasemiJirdehi, A., \& Foroudi, F. (2013). Investigation on the effects of various protein levels with constant ratio of digestible sulfur amino acids and threonine to lysine on performance, egg quality and protein retention in two strains of laying hens. Italian Journal of Animal Science, 12(1), 915. https://doi.org/10.4081/ijas.2013.e2

Moyes, C., \& Schutle, P. (2008). Principle of Animal Physiology (2nd ed.). New York: Pearson International Edition.

Newton, G. L., Booram, C. V., Barker, R. W., \& Hale, O. M. (1977). Dried hermetia illucens larvae meal as a supplement for swine. Journal of Animal Science, 44(3), 395-400. https: //doi.org/10.2527/jas1977.443395x

Nicholas, F. W. (2004). Pengantar Genetika Veteriner. Bogor: Pustaka Wira Usaha Muda.

Odetola, O., Adetola, O., Ijadunola, T., Adedeji, O., \& Adu, O. (2AD). Utilization of moringa (Moringa oleifera) leaves meal as a replacement for soya bean meal in rabbit's diets. Journal of Agricultural Science, 1(12), 309-313.

Pan, X., Chen, F., Wu, T., Tang, H., \& Zhao, Z. (2009). The acid, bile tolerance and antimicrobial property of Lactobacillus acidophilus NIT. Food Control, 20(6), 598-602. https:// doi.org/10.1016/j.foodcont.2008.08.019

Park, S.-I., Chang, B. S., \& Yoe, S. M. (2014). Detection of antimicrobial 
substances from larvae of the black soldier fly, Hermetia illucens (Diptera: Stratiomyidae). Entomological Research, 44(2), 58-64. https://doi.org/ 10.1111/1748-5967.12050

Rambet, V., Umboh, J. F., Tulung, Y. L. R., \& Kowel, Y. H. S. (2015). Kecernaan protein dan energi ransum broiler yang menggunakan tepung maggot (hermetia illucens) sebagai pengganti tepung ikan. ZOOTEC, 35(2), 13. https://doi.org/10.35792/zot. 36.1.2016.9314

Redmond, S. B., Chuammitri, P., Andreasen, C. B., Palić, D., \& Lamont, S. J. (2011). Genetic control of chicken heterophil function in advanced intercross lines: associations with novel and with known Salmonella resistance loci and a likely mechanism for cell death in extracellular trap production. Immunogenetics, 63(7), 449-458. https ://doi.org/10.1007/s00251-011-0523-y

Scanes, C. (2015). Blood. In C. G. Scanes (Ed.), Sturkie's Avian Physiology (6th ed.). London: Elsevier Inc.

Schalms, O., Jain, N., \& Carol, E. (2010). Veterinary Haematology. (D. Weiss \& K. Wardrop, Eds.) (6th ed.). USA: Blackwell Publishing Ltd.

Schiavone, A., Cullere, M., De Marco, M., Meneguz, M., Biasato, I., Bergagna, S., Dalle Zotte, A. (2017). Partial or total replacement of soybean oil by black soldier fly larvae ( Hermetia illucens L. ) fat in broiler diets: effect on growth performances, feed-choice, blood traits, carcass characteristics and meat quality. Italian Journal of Animal Science, 16(1), 93-100. https: //doi.org/10.1080/1828051X.2016.12 49968

Scott, M., Nesheim, M., \& Young, R. (1992). Nutrition of The Chicken. (M. Scott \& Associaties, Eds.) (5th ed.). New York: Ithaca.

Sh, R., El-Ghar, A., Debes, A. A., Ghanem, H. H., \& Ali, O. M. (2012). Prediction of breeding values and selection for egg mass in a closed flock of White Leghorn. Egyptian Poultry Science Journal, 32(1), 63-74. Shantibala, T., Lokeshwari, R. K., \& Debaraj, H. (2014). Nutritional and antinutritional composition of the five species of aquatic edible insects consumed in Manipur, India. Journal of Insect Science, 14(14), 1-10. https://doi.org/10.1673/031.014.14

Subowo. (2009). Histologi Umum (2nd ed.). Jakarta: Sagung Seto.

Sumardjo, D. (2009). Pengantar Kimia Buku Panduan Kuliah Mahasiswa Kedokteran dan Program Strata 1 Fakultas Bioeksakta. Jakarta: EGC.

Taruan, P. (2012). Fat Loss Not Weight Loss for Diabetes. In Sakit tapi Sehat. Jakarta: Transmedia.

Tizard, I. (2000). Veterinary Immunology an Introduction (3rd ed.). USA: Saundres.

Ulupi, N., \& Ihwantoro, T. (2014). Blood profile of kampung chicken and commercial laying hen in open house of tropical zone. Jurnal Ilmu Produksi Dan Teknologi Hasil Peternakan, 2(1), 219-223.

Ushakova, N. A., Bastrakov, A. I., Kozlova, A. A., Ponomarev, S. V., Bakaneva, Y. M., Fedorovykh, Y. V., Pavlov, D. S. (2016). Features of the effect of a complex probiotic with Bacillus bacteria and the larvae of Hermetia illucens biomass on Mozambique tilapia (Oreochromis mossambicus $\times$ O. niloticus) and Russian sturgeon (Acipenser gueldenstaedti) fry. Biology Bulletin, 43(5), 450-456. https://doi.org/10.11 34/S1062359016040130

Vercese, F., Garcia, E., Sartori, J., Silva, A. de P., Faitarone, A., Berto, D., Pelícia, K. (2012). Performance and egg quality of Japanese quails submitted to cyclic heat stress. Revista Brasileira de Ciência Avícola, 14(1), 37-41. https://doi.org/10.1590/ S1516-635X2012000100007

Vezina, F. (2003). The metabolic cost of 
avian egg formation: possible impact of yolk precursor production? Journal of Experimental Biology, 206(24), 4443-4451. https://doi.org/ 10.1242/jeb.00702

Virden, W. S., Lilburn, M. S., Thaxton, J. P., Corzo, A., Hoehler, D., \& Kidd, M. T. (2007). The effect of corticosterone-induced stress on amino acid digestibility in ross broilers. Poultry Science, 86(2), 338342. https://doi.org/10.1093/ps/86.2.338

Wagner, E. C., Prevolsek, J. S., WynneEdwards, K. E., \& Williams, T. D. (2008). Hematological changes associated with egg production: estrogen dependence and repeatability. Journal of Experimental Biology, 211(3), 400-408. https://doi.org/10.12 42/jeb.011205

Wan, X., Jiang, L., Zhong, H., Lu, Y., Zhang, L., \& Wang, T. (2017). Effects of enzymatically treated Artemisia annua L. on growth performance and some blood parameters of broilers exposed to heat stress. Animal Science Journal, 88(8), 1239-1246. https://doi.org/10.1111/a sj. 12766

Weiss, D., \& Wardrop, K. (2010). Schalm's Veterinary Hematology (6th ed.). New York: Blackwell Publishing Ltd.
Widjastuti, T., Wiradimadja, R., \& Rusmana, D. (2014). The effect of substitution of fish meal by Black Soldier Fly (Hermetia illucens) maggot meal in the diet on production performance of quail (Coturnix coturnix japonica). Scientific Papers. Series D. Animal Science, 57(1998), 125-129.

Yuwanta, T. (2010). Telur dan Kualitas Telur. Yogyakarta: Gadjah Mada University Press.

Zhu, Q. Y., Schramm, D. D., Gross, H. B., Holt, R. R., Kim, S. H., Yamaguchi, T., Keen, C. L. (2005). Influence of cocoa flavanols and procyanidins on free radical-induced human erythrocyte hemolysis. Clinical and Developmental Immunology, 12(1), 27-34. https://doi.org/10.1080/17402 520512331329514

Zulkifli, I., Che Norma, M. T., Chong, C. H., \& Loh, T. C. (2000). Heterophil to lymphocyte ratio and tonic immobility reactions to preslaughter handling in broiler chickens treated with ascorbic acid. Poultry Science, 79(3), 402-406. https://doi.org/10.10 93/ps/79.3.402 